\title{
Widzenie pustki a doświadczenie mistyczne - przypadek madhjamaki
}

\author{
Krzysztof JAKUBCZAK*
}

\begin{abstract}
Seeing of emptiness and mystical experience - the case of Madhyamaka: The problem of Buddhist religiosity is one of the most classic problems of Buddhist studies. A particular version of this issue is the search for mystical experience in Buddhism. This is due to the conviction that mystical experience is the essence of religious experience itself. The discovery of such an alleged experience fuels comparative speculations between Buddhism and the philosophical and religious traditions of the Mediterranean area. Madhyamaka is the Buddhist tradition which many researchers saw as the fulfillment of such mystical aspirations in Buddhism. In this paper I specify the standard parameters of mystical experience (non-conceptuality, ineffability, paradoxicality, silence, oneness, fullness) and I conclude that they either cannot be applied to Madhyamaka or that the application is only illusory.
\end{abstract}

\section{KEYWORDS}

Buddhism; mysticism; mystical experience; Madhyamaka; emptiness; nothingness; imputation (adbyāropa, samāropa); non-conceptuality; ineffability; paradoxicality; silence

* Dr, starszy wykładowca w Instytucie Bliskiego i Dalekiego Wschodu Uniwersytetu Jagiellońskiego w Krakowie. E-mail: x.jakubczak@gmail.com. 


\section{BUDDYZM JAKO MISTYCYZM}

„Buddyzm [...] uważać można za najbardziej mistyczną religię”. Tymi słowami znany brytyjski badacz religii Ninian Smart zaczął swój artykuł o mistyce w buddyzmie therawady (Smart, 2000: 232). Nie był on oczywiście pierwszym głoszącym tak jednoznaczny pogląd. Można tu przywołać francuskiego badacza Andre Bareau, który w pracy o buddyjskim absolucie twierdził, że „Nigdy nie należy zapominać, iż buddyzm jest przede wszystkim mistyką” (Bareau, 1951, cyt. za: Pyysiäinen, 1993: 14). Dużą rolę w popularyzacji przekonania o mistyczności buddyzmu odegrat przed II wojną światową Louis de la Vallée Poussin. W tekście poświęconym nirwanie utrzymywał, że w buddyzmie wiodą do niej dwie przeciwstawne drogi: droga racjonalnej analizy wyrażająca się $\mathrm{w}$ rozróżnianiu i wyliczaniu dharm oraz droga mistyki, tj. medytacyjnego skupienia ${ }^{1}$. Mistyki w buddyzmie dopatrywał się Theodor Stcherbatsky (Stcherbatsky, 1927: 16-19). W Polsce stanowisko takie upowszechniał Stanisław Schayer i jego uczniowie (Schayer, 1931: XXX-XXXIII). Opinie owych wybitnych badaczy przekonanie o mistycznym charakterze buddyzmu utrwaliły do tego stopnia, że wielu współczesnych autorów piszących o różnych aspektach kultury buddyjskiej przyjmuje owo przekonanie w sposób całkowicie bezkrytyczny, uważając je za niekwestionowalne².

Szczególną popularność pogląd ten uzyskał w Indiach, gdyż pozwalał niejako na powrót, wbrew oficjalnemu buddyjskiemu stanowisku, wpisać buddyzm w nadrzędną tradycję upaniszadowo-wedantyczną. Najbardziej znanym jego rzecznikiem był Tirupattur R. V. Murti, autor swego czasu bardzo poczytnej książki o madhjamace The central philosophy of Buddhism ${ }^{3}$. Ogromna popularnością cieszyły się publikacje Daisetzu Suzukiego (Suzuki, 1992: 31-33; Suzuki, 2009: 244; Suzuki, 2002) ${ }^{4}$, przesiąknięte szlachetnym aromatem buddyjskiej mistyki unoszącym się wraz z dymem japońskich kadzideł w klasztorach zen.

Sądząc po tym, jak wielu badaczy religii i samego buddyzmu w XX wieku wyrażało opinie w kwestii buddyjskiej mistyki, uznać można, że zagadnienie

${ }^{1}$ Wyróżniając te dwie drogi, Louis de la Vallée Poussin konstatował napięcie, jakie uwidacznia się w myśli buddyjskiej między tak zwanym wglądem (vipaśyanā) a wyciszeniem (śamatha) (La Vallée Poussin, 1936-1937: 189). Mimo upływu lat kwestia ta ciągle budzi kontrowersje i przykuwa uwagę badaczy.

${ }^{2}$ Zob. np. Collinson, Plant, \& Wilkinson, 2002: 379: „At the heart of Buddhism in all its forms, and so of Zen, is the experience of enlightenment, and this experience is mystical in character".

${ }^{3}$ Za zasadniczy aspekt koncepcji filozofii sformułowanej w buddyjskiej szkole madhjamaki Tirupattur R. V. Murti uważał ideę doskonałości mądrości (prajñā-pāramitā), przez którą rozumiał niedualną, beztreściową intuicję ujmującą ponadracjonalny Absolut (Murti, 1960: 218-220).

${ }^{4}$ Wypada zauważyć, że przekonanie o mistyczności buddyzmu, w tym zwłaszcza buddyzmu zen, Suzuki powtarza w pracach publikowanych po 1945 roku. We wcześniejszych tekstach zdecydowanie temu zaprzeczał (Suzuki, 1955: 74). 
to mocno skupiało na sobie uwagę badawczego środowiska. Tym bardziej zaskakuje fakt, iż doczekało się tak niewielu gruntownych opracowań. Najbardziej kompleksowe i ambitne studium tego zagadnienia pojawiło się dopiero w 1993 roku. Jest to książka Beyond language and reason: Mysticism in Indian Buddhism fińskiego badacza Ilkki Pyysiäinena (Pyysiäinen, 1993) — praca cenna ze względu na jasno, aczkolwiek dość tendencyjnie (wąsko) sformułowaną perspektywę badawczą i dobór cytatów oraz niezwykle irytująca ze względu na wiele powierzchownych i nietrafnych opinii.

Zagadnienie buddyjskiej mistyki przyciągało uwagę, gdyż jego pozytywne rozstrzygnięcie dawało nadzieję na to, iż uda się obejść problem, jaki stwarzał buddyzm swoją powszechnie znaną krytyką idei atmana (jaźni, duszy, substancjalnego podmiotu) i nieco mniej znaną krytyką idei boga kreatora. Negacja obu idei, zwłaszcza zaś tej drugiej, stawiała buddyzm poza wszelkimi esencjalistycznymi definicjami religii, które za fundamentalny aspekt wszelkiej religijności uznawały odniesienie się człowieka do boga. Całkowite dezawuowanie boskości, filozoficzna krytyka idei boskości oraz zupełne wykluczenie boskości z praktyki życiowej przy jednoczesnej afirmacji „duchowości” odbierały badaczom wygodną etykietę i burzyły utrwalone przekonania odnośnie do tego, czym jest religia. Konieczność zmierzenia się z trudnościami stwarzanymi przez buddyzm była jednym z tych kilku czynników, które wpływały na przesunięcie się uwagi badaczy religii z kwestii boga i społecznych praktyk instytucjonalizujących relację człowieka do boga na kwestię osobistego doświadczenia duchowego i jednostkowej świadomości. Ten ruch doprowadził do utrwalenia się przekonania, że sednem religijności, jej witalną energią nie są społeczne instytucje, a osobiste, niezwykle enigmatyczne doświadczenie mistyczne. Zgodnie z tym przekonaniem u źródeł wszelkiego doświadczenia religijnego ma zatem leżeć doświadczenie mistyczne. Jeżeli więc odkryjemy takie doświadczenie w tradycji buddyjskiej, to odkryjemy podstawę, w oparciu o którą będziemy mogli snuć porównawcze spekulacje z filozoficzno-religijnymi tradycjami wywodzącymi się z obszaru Morza Śródziemnego, znajdziemy zatem punkt oparcia dla uniwersalnej generalizacji.

Zdaniem wielu badaczy spełnieniem mistycznych aspiracji buddyzmu jest mahajana z jej dwiema szkołami - madhjamaką i jogaczarą. Obie owo spełnienie mają osiągać w odmienny, charakterystyczny dla siebie sposób. Na marginesie warto zaznaczyć, że mistyczność mahajany afirmują nawet ci badacze, którzy tak jak Bimal K. Matilal, kwestionują (czy też przynajmniej powątpiewają w) mistyczny charakter przesłania samego Buddy i wczesnych szkół buddyjskich z therawadą na czele (Matilal, 1975: 231-233). A nawet wtedy afirmacja ta na zasadzie kontrastu nabiera dodatkowego znaczenia, uwypuklając zdaniem tych badaczy heterodoksyjność mahajany ${ }^{5}$.

${ }^{5}$ Walter T. Stace w swojej poczytnej książce z lat sześćdziesiątych ubiegłego wieku utrzymywał, że różnice między mistycyzmem mahajany a mistycyzmem innych religii są wyłącznie 
W dalszym ciągu niniejszego artykułu zamierzam się skupić wyłącznie na szkole madhjamaki. Wskażę te miejsca w pismach twórcy szkoły, Nagardżuny, oraz w fundującej jego filozofię literaturze doskonałości mądrości, które pozwalały badaczom takie przekonanie formułować, i postaram się wykazać, że jest to przekonanie z gruntu fałszywe ${ }^{6}$.

\section{CECHY DOŚWIADCZENIA MISTYCZNEGO}

Wcześniej jednak wypada doprecyzować znaczenie kategorii „doświadczenia mistycznego", które tutaj będę miał na uwadze. Należy podkreślić, iż nie ma wśród badaczy mistyki zgody co do tego, czy wszystkie doświadczenia mistyczne mają tę samą naturę. Nie wszyscy akceptują spopularyzowane przez Williama Jamesa i dominujące od czasu publikacji jego Doświadczeń religijnych (1902) przekonanie o ich jedności (James, 2001: 292-331, zwł. 330). W latach trzydziestych XX wieku Rudolf Otto wyróżniał mistykę introwertyczną i ekstrawertyczną ${ }^{7}$. Pod koniec lat pięćdziesiątych Robert Ch. Zaehner zaproponował podział na mistykę natury (pan-en-heniczną), monistyczną i teistyczną (Zaehner, 1971: 168). Jeszcze inni, jak Gershom Scholem, podkreślali, iż mistyka przede wszystkim przynależy do określonej religii i stanowi wyraz dojrzałej religijnej świadomości, wszelkie zatem ogólne typizacje, które mistykę wyrywają z jej właściwego religijnego kontekstu, popadają nadmiernie w spekulację (Scholem, 2007: 18, 22-23).

Wreszcie należy zaznaczyć, iż nie ma również jasności co do tego, czy mistyka jest udziałem wyłącznie doświadczenia religijnego. Po eksperymentach $\mathrm{z}$ halucynogenami Aldous Huxley w latach pięćdziesiątych ubiegłego stulecia uznał, iż kontekst religijny nie jest konieczny do tego, aby wygenerować doświadczenie mistyczne, można to zrobić środkami chemicznymi (Huxley, 1991). Mimo iż stanowisko Huxleya spotkało się z ostrą krytyką ze strony religioznawców, wpłynęło na rozwój w latach sześćdziesiątych XX wieku psychologicznych badań nad doświadczeniem mistycznym. W ich efekcie pojawił się nowy język badawczy (między innymi zamiast o doświadczeniu mistycznym zaczęto mówić o odmiennych stanach świadomości), a do obiegu trafiła kategoria „mistyki halucynogenów”. Szybko jednak okazało się, że chociaż badania te wiele wnoszą do wiedzy o subiektywnych i fizjologicznych aspektach odmiennych

różnicami interpretacji, a nie doświadczenia. Czy opinię tę można odnieść do tradycji hinajany, autor uważał już jednak za co najmniej problematyczne (Stace, 1961: 123).

${ }^{6} \mathrm{Na}$ temat mistyczności szkoły jogaczary, przynajmniej w aspekcie zagadnienia niewyrażalności ostatecznej rzeczywistości, pisze David Burton (Burton, 2000).

${ }^{7}$ Ściśle rzecz ujmując, Otto mówił o mistyce „oglądu wewnętrznego" i mistyce „oglądu jedności” (Otto, 2000: 52-57). W późniejszych pracach przyjął się podział na mistykę introwertyczną i ekstrawertyczną (Stace, 1961: 131-132). 
stanów świadomości, to nie są w stanie niczego rozstrzygnąć w kwestii tego, co można by określić jako obiektywne aspekty doświadczenia mistycznego, a co gorsze sam przedmiot badawczy, jakim jest doświadczenie mistyczne, zatracił wyrazistość.

Bez wątpienia doświadczenie mistyczne jest rodzajem odmiennego stanu świadomości, nie każdy jednak odmienny stan świadomości jest doświadczeniem mistycznym. Badania psychologiczne okazały się niezdolne do określenia specyfiki doświadczenia mistycznego na tle odmiennych stanów świadomości. Uczynić to można wyłącznie powracając do starej procedury wskazywania cech charakterystycznych, której zasadniczą wadą jest to, iż wydaje się zanadto zależna od kontekstu społeczno-kulturowego. Dla realizacji celu, jaki wyznaczyłem sobie w tym tekście, to powinno jednak wystarczyć.

Wyliczanie cech charakterystycznych religijnego doświadczenia mistycznego zwykle rozpoczyna się od przypomnienia charakterystyki Jamesa. Spośród czterech cech wskazanych przez amerykańskiego filozofa dwie pierwsze spotkały się z powszechnym uznaniem i do dnia dzisiejszego przywoływane są jako najbardziej standardowe cechy tego doświadczenia (James, 2001: 293-294).

Jako pierwszą z cech wymienia się zwykle niewyrażalność. Sam James uważał ją za „najbardziej poręczną” cechę doświadczenia mistycznego, coś w rodzaju jego kamienia probierczego czy też papierka lakmusowego. Nie jest jednak jasne, jak należy ją rozumieć. Bimal K. Matilal podkreślat, iż w grę wchodzą dwie możliwości: albo kwestionujemy możliwość wyrażenia subiektywnej warstwy czy też strony doświadczenia, co wydaje się rzeczą banalną, gdyż z sytuacją taką mamy do czynienia w przypadku każdego doświadczenia zmysłowego, albo też uznajemy, że niewyrażalny jest przedmiot tego doświadczenia, i to jest zdaniem indyjskiego badacza sytuacja znacznie ciekawsza (Matilal, 1975: 218-228). Tak czy inaczej, niewielu późniejszych badaczy było gotowych poddawać w wątpliwość przekonanie Jamesa, a ci, którzy to robili, albo popadali w banał, zwracając uwagę na aspekt subiektywny (Stace, 1961: 283-284), albo kwestionowali w ogóle, tak jak Matilal (Matilal, 1975: 246-247) ${ }^{8}$, poznawczą skuteczność doświadczenia mistycznego, czyli cechę, którą James wymieniał jako drugą. Doświadczenie mistyczne bowiem, twierdził amerykański uczony, odznacza się jakością noetyczną, tj. intuicyjnym poznawczym wglądem w rzeczywistość. Obie te cechy mają wystarczać do zidentyfikowania doświadczenia mistycznego. Ponadto James dodawał jeszcze dalsze dwie drugorzędne cechy: chwilowość i pasywność.

Niewyrażalność doświadczenia mistycznego manifestować się ma w wypowiedziach mistyków na wiele różnych sposobów. Często wskazują oni na pozakonceptualną naturę doświadczanego przedmiotu. Ponieważ jest ona niedostępna

\footnotetext{
${ }^{8}$ Matilal w swojej krytyce podąża za fundamentalnym przeświadczeniem filozofii njaji, że wszystko, co istnieje, jest poznawalne i nazywalne.
} 
pojęciom, najwłaściwszym sposobem wypowiadania się o niej jest zachowanie milczenia. Mimo pochwał pod adresem językowej abstynencji mistycy z racji swojego społecznego uwikłania naruszają własne deklaracje i podejmują wysiłek nakierowania innych na drogę prowadzącą do powtórzenia ich doświadczenia. Chociaż jeszcze ważniejszym powodem wydaje się potrzeba ulokowania opartych na doświadczeniu mistycznym przekonań w obszarze dominujących modeli światopoglądowych. Czynią to, zwykle używając języka w tak dobrze znane niestandardowe sposoby: preferują negację, która choć nie wprost, to przybliżać ma nasze zrozumienie do celu, zamykając fałszywe ścieżki myśli, co jest drogą apofatyczną; orzekają sprzeczne predykaty, tak jakby logiczne przepełnienie było najstosowniejszym znakiem na oznaczenie doskonałości bytowej pełni doświadczanego przedmiotu, wyrażają się więc paradoksalnie; ubierają przedmiot doświadczenia w słowa, którym przesuwają bądź rozszerzają znaczenia, tworzą zatem retorycznie aplikowany język metafor, niepoddający się jednoznacznej wykładni'. W zabiegach tych manifestować się ma, zdaniem badaczy, charakterystyczne dla doświadczenia mistycznego poczucie jedności z doświadczanym przedmiotem, bez względu na to, czy będzie to osobowy bóg, bezosobowy absolut czy natura, poczucie jego doskonałości oraz pełni.

\section{MADHJAMAKA JAKO MISTYKA}

Które z tych cech, wypada w końcu zapytać, przysługują madhjamace? Matilal, który mistyce madhjamaki poświęcił stosunkowo wiele uwagi, uznał, iż w charakterystyce tej szkoły dominują trzy cechy mistycyzmu: (1) poznanie intuicyjne bezpośrednio ujmujące ostateczną rzeczywistość, nadrzędne względem zmysłowo-pojęciowego poznania zjawisk (sfery konwencjonalnej), (2) koncepcja niedualnej (advaya) rzeczywistości leżącej poza wielością zjawisk oraz (3) idea niewyrażalności tego, co ostateczne (Matilal, 2005: 130-131). Owa niewyrażalność ostatecznej rzeczywistości ma być zdaniem Matilala „wyrażana” w madhjamace pośrednio poprzez zastosowanie wspomnianych wyżej metod: via negativa, coincidentia oppositorum i język metafor (Matilal, 1975: 237-244).

Na poziomie literalnego czytania pism Nagardżuny łatwo wskazać fragmenty, w których metody te zdają się znajdować zastosowanie. Pisma twórcy szkoły oraz późniejszych madhjamików roją się od negacji, sprzecznych orzeczeń i określeń, których bezpośrednie znaczenie może się wydawać trudno identyfikowalne.

Już w tak zwanej mangalaśloce, czyli strofach otwierających Mulamadbjamakakariki (dalej MMK) dają się rozpoznać wszystkie te cechy. Nagardżuna składa w nich hołd Buddzie jako Doskonałemu Nauczycielowi, który oprócz nauki o zależnym powstawaniu przekazywał wiedzę o: „łagodnym uciszeniu

\footnotetext{
${ }^{9} \mathrm{Na}$ temat różnych sposobów użycia języka $\mathrm{w}$ kontekście doświadczenia mistycznego zob. teksty Richarda H. Jonesa (Jones, 1993: 101-123; Jones, 2016: 203-231).
} 
rozplenienia [tj. języka (prapañcopaśamaí śivami)], niezanikaniu, niepowstawaniu, nieunicestwieniu, nietrwałości, nietożsamości, niezróżnicowaniu, nieprzychodzeniu, nieodchodzeniu" ${ }^{\prime 10}$.

W tym samym duchu w MMK XVIII, 9 twórca madhjamaki oznajmia:

Niczym nieuwarunkowana, spokojna, pojęciowo nierozpleniona, [językowo] niezróżnicowana, bez dystynkcji — oto cecha ostatecznego [„tości” (tattvasya laksanami)] ${ }^{11}$.

Jakby tego było mało $\mathrm{w}$ rozdziale XXV traktującym o nirwanie dodaje w sposób, który zdaje się kłócić z mangalaśloką:

Nikogo i nigdzie Budda nie nauczał o uciszeniu postrzegania i łagodnym uciszeniu rozplenienia jako o czymśs ${ }^{12}$.

Z kolei Czandrakirti, wybitny komentator MMK z VII wieku, podkreśla, że: „To, co ostateczne, jest milczeniem szlachetnych” (paramārtho by ārjānāìn tūṣnìm-bhāvaḥ) (PP 57, 7-8) ${ }^{13}$, a nauka o nim, jak dopowiada w innym miejscu, jest niewysłowiona (anakșara) (PP 264, 6-7).

Owe standardowe dla mistyki formy wypowiedzi świadczące o niewyrażalności doświadczenia swoją kanoniczną podstawę mają znajdować w literaturze doskonałości mądrości. Klasycznym przykładem ma być następujący ustęp ze Strof o doskonatości mąrości będącej skarbnicą cennych cnót (Prajñā-pāramitā-ratna-guna-saincaya-gāthā):

Tak jak człowieka stworzonego czarami bądź tego, który uczynił się niewidzialnym, nie można określić słowami, tak też przekraczającego próg wolności bodhisattwę nie można określić słowami ${ }^{14}$.

${ }^{10} \mathrm{MMK}$, mangalaśloka: anirodham anutpādam anucchedam aśāśvatam, anekārtham anānārtham anāgamam anirgamam, yạ̣ pratītya-samutpādaì prapañcopaśamaì śivam (wszystkie cytaty z sanskrytu w przekładzie autora). Mangalaśloka bywa różnie traktowana w różnych redakcjach. W uchodzącej za normatywną redakcji Louisa de la Vallée Poussina strofy te zostały wyodrębnione z pierwszego rozdziału (zob. La Vallée Poussin, 1903: 11, w. 13-16). Czasami jednak włącza się je do rozdziału pierwszego jako jego strofy otwierające, co jednak ze względu na ich treść wydaje się nieuzasadnione (Vaidya, 1960: 4). Czasami zaś strofy te w redakcji MMK są w ogóle pomijane, jak ma to miejsce w redakcji Jana W. de Jonga (Jong, 1977: 1).

${ }^{11}$ MMK XVIII, 9: apara-pratyayai் śāntam prapañcair aprapañcitam, nirvikalpam anānārtham etat tattvasya lakșanam.

${ }^{12}$ MMK XXV, 24: sarvopalambhopaśamaḥ prapañcopaśamaḥ śivaḥ, na kvacit kasyacit kaścid dharmo buddhena desita.

${ }^{13}$ Określenie „milczenie szlachetnych / szlachetne milczenie” jest w kulturze buddyjskiej głęboko zakorzenione i możliwe, że posługiwał się nim Budda. W zbiorze sutt kanonu palijskiego pojawia się co najmniej trzykrotnie, zob. SN II, 273; AN IV, 153; MN I, 161. W madhjamace nabiera jednak szczególnego znaczenia.

${ }^{14}$ RGS XX, 20: yatha nirmito purușa no va adrisyakāyo nāmena vā puna sa prajñapanāya śakyah, tatha bodhisattva caramāṇu vimokșadvāram nāmena vā puna sa prajñapanāya śakyah. 
Jak należy rozumieć takie wypowiedzi? Uprzedzając wypadki, stwierdzę, że przede wszystkim należy je staranniej czytać, uwzględniając ich własny kontekst, a nie pochopnie narzucać interpretacje, kojarząc je z utrwalonymi kulturowymi schematami. Stwierdzenie, iż osoby zrealizowanej (tutaj: bodhisattwy) nie można określić słowami, nie musi bowiem znaczyć, iż ontyczny stan takiej osoby jest w sensie dosłownym nieopisywalny. Podobne stwierdzenie pojawiło się już w Dhammapadzie odnośnie doskonałego. Głosi się tam, że jego droga jest nieuchwytna, gdyż nie zostawia on śladów karmicznych, tak jak ptak nie zostawia śladów w powietrzu (DhP VII, 92) ${ }^{15}$. Nieopisywalność więc w pierwszym rzędzie nie dotyczy, a przynajmniej nie musi dotyczyć bodhisattwy, a faktu nietworzenia karmana - nie sposób opisać to, czego nie ma. Co ciekawe, owo porównanie zrealizowanego do ptaka pojawia się też w Ratnagunie/Asztasabasrice, i to w tym samym rozdziale, co przytoczona strofa (RGS XX, 8/AS XX, 374), i to ono wyznacza kontekst dla rozumienia nieokreśloności bodhisattwy.

Wróćmy jednak jeszcze na moment do dalszych przykładów paradoksalnego orzekania w sutrach doskonałości mądrości. Niezwykle ciekawe twierdzenie pojawia się w pierwszym rozdziale Asztasabasriki (AS I, 21-22). W odpowiedzi na pytanie Subhutiego Budda wskazuje na szczególną i niezwykłą cechę postawy bodhisattwy związaną z treścią jego ślubowania. Jak wiadomo bodhisattwa zobowiązuje się do niesienia pomocy wszystkim sansarycznym istotom celem doprowadzenia ich do nirwany. Doprowadzając jednak do nirwany niezliczone istoty - stwierdza Budda - bodhisattwa nikogo do nirwany nie doprowadza. Co więcej, nie tylko nikt nie zostaje do nirwany doprowadzony, ale też nie istnieje nikt, kto mógłby kogokolwiek do nirwany doprowadzić. Na poziomie literalnym mamy więc klasyczną sprzeczność — działanie, które domaga się podmiotu działania i przedmiotu działania, ma być wykonane przez nieistniejący podmiot wobec nieistniejących przedmiotów.

Podobnych paradoksalnych wypowiedzi w sutrach doskonałości mądrości znajdujemy wiele: a to Tathagatę należy widzieć na podstawie nie-cech jako cech $^{16}$,

Prajñā-pāramitā-ratna-guna-saincaya-gāthā (dalej przywoływana też w spolszczonej skróconej wersji jako Ratnaguna) jest syntetyczną, składającą się z 302 strof (gāthā), wersją Sutry doskonatości mądrości w ośmiu tysiącach strof (Asța-sāhasrikā-prajñā-pāramitā-sūtra; dalej przywołuję ją też w skróconej spolszczonej wersji jako Asztasabasrika). Obie wersje uważa się za najstarsze teksty literatury doskonałości mądrości, których początek datowany jest na I wiek p.n.e. Z całą pewnością jednak ich obecna forma kształtowała się przez dłuższy czas i, co ważne, nie ma między nimi pełnej odpowiedniości (Conze, 1952: 251-262).

${ }^{15}$ Dhammapada to zbiór 423 strof przypisywanych przez tradycję samemu Buddzie. Tekst uważa się za wczesny, aczkolwiek nie sposób jednoznacznie określić daty jego powstania. Już w początkowym okresie swojego istnienia musiał cieszyć się niezwykłą popularnością, o czym świadczyć może fakt, iż zachował się w kilku redakcjach (różnej długości) i językowych wersjach. Również dzisiaj jest to jeden z najpopularniejszych buddyjskich tekstów (Norman, 1989: 153).

${ }^{16}$ VC 5: lakșanālakșanatastathāgato draștavyah. Por. też RGS I, 12c, gdzie oznajmia się, że: „Praktykę tę [bodhisattwa] rozpoznaje jako nie-praktykę” (caranam ca so acaranam ca 
a to bodhisattwa nie powinien się chwytać ani dharmy (cnoty/cechy), ani nie-dharmy (nie-cnoty/nie-cechy) ${ }^{17}$, za to bodhisattwa powinien porzucić dharmy (cnoty/cechy) jeszcze bardziej niż nie-dharmy (nie-cnoty/nie-cechy) $)^{18}$ itd.

Wypowiedzi te pozostawione bez komentarza zdają się naruszać podstawową logiczną intuicję rządzącą naszym językiem - prawo niesprzeczności ${ }^{19}$. Czy faktycznie pozostaje nam tylko skonstatować ten fakt i uznać, że są rozpaczliwą próbą wysłowienia niewysławialnego? Zdecydowanie nie mogę na to przystać. Wczytajmy się ponownie w słowa obwieszczające beznadziejny los bodhisattwy - ma on do nirwany doprowadzić niezliczone istoty, nie doprowadzając żadnej. Sądzę, że rozwiązanie tego paradoksu, jakie proponuje Vajracchedikāa- prajūā-pāramitāa-sūtra ${ }^{20}$, należy przyjąć za paradygmatyczne. Stwierdza się w niej, iż nie można uznać za bodhisattwę tego, kto wciąż działa w oparciu o pojęcie ja/jaźni, żywej istoty, duszy, osoby ${ }^{21}$.

Zresztą nie jest to rozwiązanie oryginalne. Pojawia się już w Asztasahasrice (I, 11-14), aczkolwiek $\mathrm{w}$ formie mniej wyrazistej, gdyż narracyjnie bardziej rozbudowanej. Po orzeczeniu powszechnej pustki (AS I, 10) Subhuti,

prajānayitvā), a także RGS II, 7d, gdzie po stwierdzeniu, że bodhisattwa ćwiczy się wyłącznie w nauce Buddy celem osiągnięcia wszechwiedzy, ogłasza się, że: „Jego [bodhisattwy] ćwiczeniem jest nie-ćwiczenie i nikt nie ćwiczy się w takim ćwiczeniu" (śikșāaśikșa na ya śikșati eșa śikșā).

${ }^{17}$ VC 6: na [...] bodhisattvena mahāsattvena dharma udgrabītavyo nādharmah.

${ }^{18} \mathrm{VC}$ 6: dharmā eva prabātavyāh prāgevādharmā. Kwestia tłumaczenia terminu dharma w tym fragmencie, zwłaszcza gdy pojawia się w liczbie mnogiej, budzi ogromne kontrowersje, a sam termin bywa różnie przekładany. Ponieważ rozstrzygnięcie tej kwestii w tym miejscu nie jest ważne, nie wdaję się w dyskusję. Por. też słynne sformułowanie z VC 8, w którym oznajmia się, że Tathagata nauczał, iż cechy Buddy są nie-cechami Buddy i dlatego właśnie nazywane są cechami Buddy (buddha-dharmā buddha-dharmā iti subbūte abuddha-dharmāścaiva te tathāgatena bhāsitāh, tenocyante buddha-dharmā iti).

${ }^{19}$ Bez wątpienia tego typu wypowiedzi stanowią literalną podstawę dla sformułowanej przez japońskiego filozofa Kitaro Nishidę koncepcji absolutnej nicości i absolutnie sprzecznej samotożsamości, na ten temat zob. Heisig, 2001: 61-83; Kozyra, 2007: 29-70. Jak jednak wykazuję dalej, sprzeczności owe należy uważać za pozorne, a tym samym koncepcja Nishidy pochopnie i mylnie nadinterpretowuje sutry doskonałości mądrości.

${ }^{20}$ Vajracchedik̄a-prajñā-pāramitā-sūtra, czyli Sutra doskonałości mądrości [będąca jak] diamentowe ostrze jest tekstem o niepewnym datowaniu. Obok klasycznej opinii Edwarda Conzego, wyznaczającej powstanie tego tekstu na okres 350-400 n.e., popularnością cieszy się też przekonanie, że sutra ta należy do starszych tekstów literatury doskonałości mądrości i może być niewiele młodsza od Asztasabasriki, na ten temat zob. Schopen, 1975: 153, przyp. 16-17; Williams, 1989: 41-42. Dalej ten tekst przywołuję jako Sutra diamentowa - pod tym tytułem, chociaż nieoddającym dokładnie sensu oryginału, dzieło to się spopularyzowało i jest powszechnie znane.

${ }^{21} \mathrm{VC}$ 3: na sa [...] bodbisattvo vaktavyo yasya sattva-samiñ̄a pravarteta jivva-samjiña vā pudgala-saimjñā va pravarteta. Por. RGS I, 24-25 - wielkie współczucie bodhisattwów jest wolne od pojęcia istoty/bytu; ten, kto myśli, że przekroczył cierpienie, myśli w kategoriach istot i jaźni - nie posiada mądrości. Por. RGS VII, 4 - kto myśli, że dąży do mądrości, aby uwolnić inne istoty, wyobraża sobie pojęcie istot i nie praktykuje tym samym doskonałości mądrości. 
uwzględniając fakt pustki, przystępuje do charakterystyki postępowania bodhisattwy. Znamienne w owej prezentacji jest to, iż zaczyna od określenia niewłaściwej postawy umysłu tego, który aspiruje do ideału bodhisattwy. Nie zbliża się do realizacji tego ideału - oznajmia Subhuti - ten, kto działa w oparciu o którykolwiek z pięciu zespołów czynników (skandha). Ten, kto tak działa, faktycznie działa w oparciu o znak (nimitta). W oparciu o znak działa każdy, kto działa w oparciu: o znak formy (rüpa-nimitta); o wyobrażenie, że „forma jest znakiem"; o powstawanie formy; o zanik formy; o zniszczenie formy; o wyobrażenie, że „forma jest pusta”; o wyobrażenie „ja działam”; czy też o wyobrażenie ,ja jestem bodhisattwą" i tak dalej odpowiednio do czterech pozostałych zespołów. Ten, kto w ten sposób działa — mówi Subhuti — „faktycznie działa w oparciu o wyobrażenie «ja jestem bodhisattwą» [traktowanym] jako podstawa"22. Dopóki ktoś myśli o sobie, że działa w oparciu o doskonałość mądrości, dopóty działa w oparciu o znak. Ostatecznie Subhuti podsumowuje: „taki bodhisattwa znany jest jako niezręczny w środkach"23.

Powyższa negatywna charakterystyka rodzi pytanie o to, jak od strony pozytywnej powinno wyglądać działanie tego, który działa w oparciu o doskonałość mądrości. W odpowiedzi Subhuti ponownie wylicza rzeczy, w oparciu o które nie należy działać, dodając, że ten, kto działa niewsparty o te rzeczy, nie powinien nawet myśleć, że działa w oparciu o doskonałość mądrości. Działając, nie tworzy wyobrażeń ,ja działam”, ,ja nie działam”, ,ja działam i nie działam”, „ja ani działam, ani nie działam”. Właściwym stanem umysłu bodhisattwy jest „skupienie na nielgnięciu do żadnych dharm poprzez nazwę"24. Ostatecznie stwierdza Subhuti - „kiedy trwa w tym skupieniu, bodhisattwa mahasattwa szybko osiągnie pełne doskonałe przebudzenie" 25 , a trwając w tym skupieniu nie myśli o sobie „ja jestem skupiony”. Co ciekawe, będąc tak skupionym dodaje Subhuti - bodhisattwa nie jest w stanie takiego skupienia zademonstrować, gdyż go nie zna i nie postrzega, a nie zna go i nie postrzega, gdyż ono nie istnieje (AS I, 14). Oto mamy dramatyczny paradoks — żeby zrealizować postawę bodhisattwy, musimy wejść w skupienie, które nie istnieje. Jest to jednak paradoks pozorny, jak można wnosić z kolejnych słów, tym razem wypowiedzianych przez Buddę. Skupienie to nie istnieje w tym sensie - oznajmia Czcigodny - iż nie istnieje jako ontyczny czynnik (dharma), którego własną cechą, własną naturą byłaby jakość takiego skupienia. Skupienie to nie jest

${ }^{22}$ AS I, 11: abaim bodbisattva iti by upalambha eva sa carati. Tekst ten przywołuję w paginacji z pierwszej redakcji Rajendralali Mitry z 1888 roku, którą przyjął i upowszechnił w swoim tłumaczeniu Conze, chociaż ze względu na wygodę użycia zwykle korzystam z redakcji Paraśuramy L. Vaidyi z 1960 roku.

${ }_{23}$ AS I, 12: ayam bodhisattvo 'nupāya-kuśalo veditavyạ.

${ }^{24}$ AS I, 13: sarva-dharmānupādāno nāma samādbir.

${ }_{25}$ AS I, 13: anenaiva samādhinā viharan bodhisattvo mabāsattvạ̣ kṣipram anuttarāim samyaksambodbim abbisambudhyate. 
czynnikiem umysłu, dlatego, że w ogóle żadne czynniki, tj. dharmy w sensie ostatecznym, czyli jako obdarzone własną naturą i w sobie ugruntowane, nie istnieją. Ponieważ nie ma niczego, co tak by istniało, to niczego tak istniejącego nie można poznać i doświadczyć, a tym samym nie można tego pokazać. Trwanie w skupieniu na nielgnięciu do żadnych dharm nie polega na doświadczeniu szczególnej umysłowej jakości jako przynależnej pewnemu dharmie, lecz na uświadomieniu sobie, że nie istnieją żadne jakości jako przynależne dharmom ${ }^{26}$.

Zaproponowana w Asztasabasrice i powtórzona zwięźle w Sutrze diamentowej wykładnia znosi sprzeczność, gdyż ujawnia jej pozorność. Wykluczające się orzeczenia nie dotyczą tego samego przedmiotu pod tym samym względem. Ślubowanie niesienia pomocy jest aktem sansarycznym, to znaczy dokonującym się w oparciu o sansaryczny, tj. obarczony niewiedzą, sposób postrzegania istot. Aby jednak to ślubowanie wypełnić, ślubujący musi zmienić, musi przekształcić swój ogląd rzeczywistości ${ }^{27}$, musi rozpoznać podstawowy fakt buddyjskiej nauki - w sensie ostatecznym nie ma żadnych istot ufundowanych na trwałych, niezmiennych i substancjalnych jaźniach, żadnych atmanów, jak też i żadnych ostatecznych w sobie określonych i w sobie ufundowanych dharm. Pojęcie istoty, tak jak pojęcie dharmy, jest funkcjonalne wyłącznie w obszarze sansary, tj. w obszarze doświadczenia sansarę konstytuującego, rozpoznanie tego faktu jest warunkiem realizacji nirwany, a ta wiąże się z całkowitym zaprzestaniem lgnięcia i właśnie, jak stwierdza Asztasabasrika, „bodhisattwa mahasattwa jest tym, który ćwiczy się w nieprzywiązaniu do żadnych dharm"28.

\section{PUSTKA A NICOŚĆ}

Madhjamaka głosi, iż wszystko, czego doświadczamy i czego doświadczyć możemy, jest puste, czyli nie posiada samobytu. Niewiedza, która warunkuje naznaczony cierpieniem stan sansaryczny, dotyczy tego właśnie faktu. Jedynym sposobem, aby tę sytuację zmienić na satysfakcjonującą, jest korekta owego poznawczego błędu, która może się dokonać wyłącznie poprzez bezpośredni ogląd stanu faktycznego. W Sześćdziesięciu strofach rozumowania (Yukti-șaștikā-kārikā) Nagardżuna oznajmia:

Gdy widzi się, [że wszystko], tak jak człowiek stworzony czarami, jest puste (t. dben pa = s. vivikta), osiąga się nirwanę 29 .

${ }^{26} \mathrm{Na}$ tej samej zasadzie w Sutrze diamentowej oznajmia się, że pełne doskonałe przebudzenie nie jest dharmą i dlatego właśnie, że nie można w nim znaleźć ani uchwycić żadnego dharmy, nazywane jest pełnym doskonałym przebudzeniem; zob. VC 22, por. też VC 7.

${ }^{27} \mathrm{Na}$ temat języka jako narzędzia soteriologicznej transformacji $\mathrm{w}$ tradycji buddyjskiej zob. Yao-ming, 2014: 330-345.

${ }^{28}$ AS I, 18: sarvadharmānāim bi subhūte bodbisattvo mahāsattvo 'saktatāyām śikṣate.

${ }^{29}$ YṢ 56cd: sgyu ma'i skyes bu ltar dben par, mthong nas mya ngan 'da' bar 'gyur. 
Nie będę w tym miejscu objaśniał szczegółowo całego słownika madhjamaki, w którym kluczową rolę pełni termin „samobyt” (svabhāva). Nie będę tutaj eksplikował znaczenia „pustki” jako braku. Nie chcę się wdawać w dyskusję na temat dwóch aspektów samobytu - egzystencjalnego i esencjalnego - i ich wzajemnych powiązań. O tym wszystkim pisałem obszernie w innym miejscu (Jakubczak, 2010: 173-177) i nie chcę do tego wracać.

Tym, co mnie tutaj interesuje, nad czym chcę przez chwilę podywagować, jest pytanie: $\mathrm{Na}$ czym faktycznie polega błąd istot sansarycznych? Czym jest owo niewidzenie pustki?

W MMK XV, 6 Nagardżuna udzielił pewnej podpowiedzi. Czytamy tam:

$\mathrm{Ci}$, którzy widzą samobyt i innobyt, byt i niebyt, nie dostrzegają istoty (tattva) nauki Buddy $^{30}$.

Zatem pustki nie widzą ci, którzy widzą samobyt i pozostałe ufundowane na nim kategorie. Czym jest jednak to widzenie samobytu, jak ono wyraża się w naszym codziennym doświadczeniu?

Właśnie siedzę za stołem, który, jak uważam, prezentuje mi się bezpośrednio w całej swojej solidności. Mogę się o niego oprzeć, ufając, że moje dłonie napotkają opór, mogę bezrefleksyjnie położyć na nim kolejną kartkę w przekonaniu, że pozostanie w zasięgu mojej ręki, mogę dla gimnastyki zajrzeć pod spód, nie zadając sobie wcześniej pytania, czy w ogóle ten stół ma jakiś spód. Skąd we mnie zaufanie, jakim obdarzam ten przedmiot? Dlaczego z podejrzeniem słucham madhjamika, gdy mówi mi, że to jest tylko byt nominalny (prajñapti-mātra) i co to właściwie miałoby znaczyć?

Sytuacja, którą próbuję tutaj opisać, została w dwudziestowiecznej filozofii poddana analizie przez Edmunda Husserla. Nazwał on ją "generalną tezą naturalnego nastawienia” (Husserl, 1975: 86-88). Sądzę, że dokładnie ten sam aspekt naszego codziennego doświadczenia ma na myśli Nagardżuna, gdy mówi o „widzeniu samobytu”. Widzieć samobyt to doświadczać przedmiot jako to, co napotykam, jako to, co znajduję w świecie, jako to, przed czym staję, dążąc do odkrycia zamkniętej w nim samym jego własnej tajemnicy. Widzieć samobyt to wpisywać w przedmiot doświadczenia poczucie naturalności jego bycia danym. Czandrakirti w Prasannapadzie sytuację tę określił mianem „nakładania/przypisania" (adbyāropa) fałszywej natury / fałszywego samobytu (viparīta-svarūpa = viparita-svabhāva $)^{31}$, dodając, iż właśnie ten akt nakładania samobytu poddał krytyce Nagardżuna w pierwszym rozdziale MMK, rozwijając filozofię pustki.

\footnotetext{
${ }^{30} \mathrm{MMK}$ XV, 6: svabhāvaim parabhāvaì ca bhāvaì cābhāvam eva ca, ye paśyanti na paśyanti te tattvaì buddha-śāsane.

${ }^{31}$ PP 58, 10-11: „Dlatego pierwszy rozdział zaczyna się najpierw [stwierdzeniem] «rzeczy nie powstały», aby przeciwstawić się nakładaniu fałszywej natury” (tasmād anutpannā bbāvā ityevaì tāvad viparīta-svarūpädhyāropa-pratipakșeṇa prathama-prakaraṇārambhaḅ). Termin
} 
Nominalność przedmiotu, zdaniem madhjamika, nie polega na tym, że wyprojektowuję go w całym jego jakościowym uposażeniu. To jest pogląd jogaczary i jest to pogląd idealistyczny. Nominalność przedmiotu polega na tym, iż ujmuję go jako samoistny. Zobaczyć pustkę przedmiotu to utracić owo poczucie naturalności dania, ale nie sam przedmiot. Pustka madhjamaki nie jest zatem transcendentną rzeczywistością ukrytą pod płaszczem danej nam w doświadczeniu mnogości rzeczy.

Analiza, którą postuluje madhjamik, ma ujawniać, że konwencjonalne przedmioty, czyli przedmioty doświadczenia codziennego, nie istnieją tak, jak się jawią, czyli jako samoistne i samobytujące, ale nie, że nie istnieją w ogóle. Analiza ujawnia, że mylimy się co do ich sposobu istnienia, ale nie co do samego ich istnienia.

Odkrycie, że wszystko, co jest nam dane, istnieje tak samo, staje się podstawą orzekania jedności rzeczy. Ciekawy tego przykład odnajdujemy w Pańczawińsiatisabasrice. Sutra stwierdza analogicznie do przywoływanej wcześniej Asztasabasriki, że bodhisattwa, który zmierza do doskonałości mądrości, opierając się na formie (rūpa) i pozostałych zespołach (skandha), jest niesprawny w użyciu środków (anupāya-kuśala). Zręczny w środkach jest tylko ten, który nie opiera się na formie itd., to znaczy ten, który widzi, że nic nie ma samobytu, łącznie z samą mądrością (PVS 1,140). Zobaczyć, że nic nie ma samobytu, to zobaczyć, że ostatecznie, to znaczy jako w sobie określone, nic nie istnieje, w szczególności nie istnieją żadne dharmy (sarva-dharma-avidyamānatva) jako nośniki własnych istotowych jakości. Zatem wszystkie dharmy, jako że są nierozróżnialne (avikalpatva) w oparciu o przynależne im cechy, ostatecznie są takożsame (sarva-dharma-samatā). Na tej podstawie formułowane jest również przekonanie o nierozróżnialności żadnych medytacji oraz o nierozróżnialności medytacji i bodhisattwy (medytacji i przebudzenia) (PVS 1, 145) ${ }^{32}$.

adbyāropa należy do grupy kilku równoznacznych terminów utworzonych na bazie rdzenia czasownikowego rub ('wznosić (się), wspinać się, nakładać, przypisywać). W grupie mamy także āropa i samāropa. Wszystkie znaczą 'nałożenie'. Czandrakirti używał go wymiennie właśnie z samāropa. Termin ten nie jest wyłączną własnością Czandrakirtiego i madhjamaki. Ważną rolę uzyskał we wcześniejszej widżnianawadzie. Z kolei dla Siankary jest on synonimem terminu adbyāsa również w znaczeniu 'nałożenia', który to termin należy do zestawu najbardziej podstawowych kategorii adwajtawedanty, gdzie używa się go do definiowania niewiedzy avidyā. Rację mają ci badacze, którzy twierdzą, że w zrozumieniu owego pojęcia kryje się klucz do istoty nauki o pustce rzeczy, zob. np. Tanji, 2000: 353; Tillemans, 2001: 16. Problem polega jednak na tym, że nie jest łatwo ten klucz wydobyć, gdyż kategoria „nakładania” może być i bywa różnie rozumiana. Późniejsi madhjamikowie, jak Kamalasila i Dżnianagarbha, preferowali synonim samāropa, zapożyczony z filozofii widżnianawady, zob. Tanji, 2000: $347-348$.

${ }^{32} \mathrm{~W}$ stwierdzeniach tego rodzaju należy dopatrywać się źródeł twierdzenia Dogena o jedności zazen i przebudzenia. Jedność zazen i przebudzenia jest jednością pustki, a nie pełni, jest jednością braku/negatywną, a nie posiadania/pozytywną. 
Podkreślić należy z naciskiem, iż pustka nie jest ostateczną rzeczywistością w takim sensie, jak bóg teistów, Jedno neoplatoników czy brahman wedantystów, nie jest gruntem w sensie ontycznej podstawy wszystkiego. Pustka jest ostateczną ,jakością” wszelkiego możliwego przedmiotu doświadczenia, to znaczy jest faktem nieposiadania domniemanego w naturalnym nastawieniu samobytu jakiejkolwiek rzeczy odkrywanym na drodze analizy. Ci, którzy przypisują madhjamace mistycyzm (Matilal, 1975: 220), ten fakt przeoczają, ulegając wedantyczno-neoplatońskim nawykom.

Tak rozumiana pustka nie ma nic wspólnego z ideą nicości. Snucie na jej podstawie porównań między buddyzmem (madhjamaką) a chrześcijańską bądź wedantyczną mistyką jest w punkcie wyjścia skazane na porażkę. W chrześcijańskim doświadczeniu mistycznym nicość pojawia się w dwóch postaciach, obie są spadkiem po tradycji neoplatońskiej (i Filona z Aleksandrii). Po pierwsze nicość Boga, czyli absolutnego bytu, który w swojej doskonałej absolutności wykracza poza pojęcie bytu ukształtowane w świecie codziennego doświadczenia. Będąc ostatecznym gruntem dla wszelkiego istnienia, nicość taka jest nicością nieokreśloności czy też nieokreślonej ponadracjonalności, nicość taka jest faktycznie Nicością. Po drugie nicość stworzenia, które w sobie jest nicością o tyle, o ile nie ma w nim niczego, co nie pochodziłoby od Boga. Jest to nicość w rozumieniu całkowitej pochodności istnienia. Chrześcijańskie doświadczenie mistyczne jest zwróceniem się ku boskiej Nicości poprzez odkrycie nicości świata.

Pustka madhjamaki jest podstawą wszelkich form w świecie nie w sensie gruntu, w którym zakotwiczony jest byt wszelkich form (rzeczy). Pustka nie jest tu ani nicością jako absolutnym przekreśleniem bytu, ani nicością jako nieokreślonością doskonałego absolutnego bytu. Pustka jest bezistotowością rzeczy (form) będącą wyrazem ich wzajemnej zależności/relacyjności. Pustka jest naturą rzeczy w sensie braku wszelkiej natury, to znaczy w sensie niebycia określonym od wewnątrz, ze swej własnej strony ${ }^{33}$.

Buddyjskie rozumienie pustki jako niesubstancjalności wszelkiego istnienia nie ma też nic wspólnego $\mathrm{z}$ hinduistycznym, tak ważnym $\mathrm{w}$ tradycji wedanty rozumieniem pustki jako nieprzejawionym istnieniem Absolutu, a przez to istnieniem niepoznawalnym, zainicjowanym w Rigwedzie w hymnie Nasadija $(\text { Rg-veda X, 129, 3) })^{34}$. W idei pustki wyraża się buddyjskie rozumienie istnienia jako relacyjności: rzeczy są tym, czym są poprzez relacje, a nie są w relacji poprzez bycie tym, czym są. Tak rozumiana relacyjność przysługuje wszelkiemu

${ }^{33}$ Dlatego Tathagatę, jak zauważa VC 5, należy widzieć na postawie nie-cech jako cech, czyli na podstawie braku natury jako natury. Czandrakirti wyraził tę myśl wprost: naturą rzeczy jest ich brak natury, to znaczy tym, co ostateczne w rzeczach, jest fakt, iż nie posiadają one żadnej natury w rozumieniu esencjalnym, zob. na ten temat Ames, 1982: 161-177.

${ }^{34} \mathrm{~W}$ języku polskim hymn ten przekładany był co najmniej dziewięciokrotnie. Przegląd tłumaczeń, analizę tekstu wraz z własną propozycją translatorską daje Maria Krzysztof Byrski (Byrski, 2008: 153-172). 
istnieniu. Jest to jeden z powodów, dla których buddyzm odrzuca ideę Boga jako w sobie ugruntowanego gruntu wszelkiego różnego od siebie istnienia.

Czytając o ostatecznym, które ma się kryć pod takimi terminami jak paramārtha, tattva, tathatā czy dharmatā, badacze zbyt pochopnie ulegali neoplatońskim nawykom, które skłaniały ich do postulowania transcendencji jako faktycznego desygnatu owych terminów. Wskazując na to, co ostateczne, teksty madhjamaki i sutry doskonałości mądrości faktycznie wskazują na pustkę jako na brak samobytu. Znamienne tego potwierdzenie znajdziemy w Ratnagunie, która dobitnie określa, jak należy ową takość rozumieć. W strofie XII, 4 czytamy:

Bez względu na to, czy mędrcy przebywają w świecie, czy weszli w ostateczną nirwanę, owa natura rzeczy (tj. dharmiczność) (dharmatā) pozostaje wykazana: „Dharmy są puste". To jest owa takość (tathatā), którą pojmują bodhisattwowie ${ }^{35}$.

Zatem jeżeli w ogóle możemy mówić z perspektywy nauki o pustce, że rzeczywistość jest niedualna (advaya), to nie w sensie substancjalnej tożsamości wszelkiego bytu, lecz w sensie jego esencjalnej takożsamości. Wszystko, co jest bądź może być dostępne w naszym doświadczeniu, w ten sam sposób pozbawione jest samobytu. Tak radykalne zaprzeczenie samobytu ma zdaniem wielu krytyków madhjamaki prowadzić do ekstremalnych konsekwencji - do nihilizmu. Badacze głoszący mistyczną wykładnię myśli madhjamaki wmawiają nam jednak, że lekarstwem na domniemany jej nihilizm jest absolutyzm. W ich opinii negatywna droga madhjamaki jest radykalna, ale tylko w dążeniu do ukrytej prawdy pełni bytu. Badacze ci nie chcą dostrzec, iż Nagardżuna w zgodzie z wczesnymi buddyjskimi intuicjami powtórzonymi w literaturze doskonałości mądrości twierdził, że obie postawy - nihilizm i absolutyzm - są objawami tej samej choroby, z której leczyć miała nauka o pustce.

\section{SENS MILCZENIA W MADHJAMACE}

W tym miejscu musimy jednak zapytać, czy nauka o pustce jako o ostatecznym stanie rzeczy jest w ogóle wyrażalna. W kontekście różnych stwierdzeń sugerujących niewyrażalność buddyjskiej nauki czy też wręcz postulujących zachowanie milczenia w obliczu ostateczności pytanie to nabiera szczególnej wagi.

W Sutrze diamentowej Budda oznajmił Subhutiemu:

Ta dharma, nauczana przez Tathagatę, jest nieuchwytna (agrābya), jest niewyrażalna (anabbilapya). Nie jest to ani dharma, ani nie-dharma ${ }^{36}$.

${ }^{35}$ RGS XII, 4abc: tișthantu loka-vidunām parinirvrtānāmi sthita eșa dbarmata-niyāma śūnya-dharmā, tām bodhisattva tathatām anubuddhayanti.

${ }^{36} \mathrm{VC}$ 7: yo 'sau tathāgatena dharmo deśitạ, agrāhyah so 'nabbilapyạ, na sa dharmo nādharmah. 
Przekonanie o niemożliwości wysłowienia dharmy powtórzył Czandrakirti. W Prasannapadzie po stwierdzeniu, że własna natura (svarūpa) ani istnieje, ani nie istnieje, oznajmił, iż „na zasadzie konwencji i poprzez przypisanie mówimy, że «rzeczy istnieją», aby rozwiać u ludzi lęk"37. W swoim postępowaniu - dodaje Czandrakirti, cytując niezidentyfikowaną sutrę - madhjamikowie postępują za Czcigodnym, który miał oznajmić:

Jak można przyswoić niewysłowioną (anakșara) dharmę? Jak można nauczyć niewysłowionej dharmy? Niewysłowiona prawda jest przyswajana i nauczana dzięki przypisaniu $(\text { samāropa })^{38}$.

Odpowiedź na pytanie o to, co znaczy, że nauka jest niewysłowiona, pokrywa się z odpowiedzią na pytanie o to, jaki jest sens milczenia w madhjamace. Aby się do niej zbliżyć, powinniśmy sobie $\mathrm{w}$ pierwszym rzędzie uświadomić, że milczenie ze względu na kontekst, w jakim się pojawia, nie zawsze znaczy to samo. Uwzględniając to, proponuję roboczo wyróżnić i rozważyć cztery idee milczenia.

Milczenie (uświadomionej) niewiedzy — to milczenie wskazujące na nieznajomość odpowiedzi. Milczę, gdyż uświadamiam sobie, że odpowiedź nie jest mi znana. Jego warunkiem jest zrozumienie pytania.

Milczenie sceptyka - milczenie to jest skutkiem decyzji o zawieszeniu wszelkich sądów na temat rzeczy ze względu na skonstatowanie niemożliwości rozstrzygnięcia prawdziwości ani fałszywości żadnego sądu asertywnego oraz sprzecznego z nim sądu negatywnego. Jest ono wyrazem fundamentalnych ograniczeń poznawczych człowieka. Człowiek w swoim poznaniu nie jest w stanie wyjść poza sferę własnych, tj. subiektywnych wrażeń i doznań, a tym samym poza sferę mniemań. Milczenie to jest ostateczną konkluzją wypływającą z analizy zdolności poznawczych człowieka. Konsekwentny sceptyk powinien całkowicie milczeć na temat wszelkiego bytu różnego od jego własnych wrażeń. Za swoistą wersję takiego milczenia należałoby uznać milczenie postmodernisty (poststukturalisty, dekonstrukcjonisty), o ile ten w imię względności wszelkiej prawdy uznałby za stosowne zaprzestać wieszczenia owej „prawdy” (Szahaj, 1993: 11-12).

Milczenie mistyka - milczenie to wskazuje na całkowicie nieempiryczny charakter bytu transcendentnego. Tylko pozornie przypomina ono milczenie sceptyka. Bardziej niż świadectwem niemożliwości poznawczych człowieka jest wyrazem pozapojęciowej natury bytu transcendentnego. Rozpoznanie owej pozapojęciowej natury dokonuje się w procesie poznawczym skupionym na świecie dostępnym poznawczo, czyli świecie rzeczy. To rozpoznanie natury świata rzeczy każe nam uznać istnienie owej transcendencji jako ostatecznego

\footnotetext{
${ }^{37}$ PP 264, 4: tathāpi śrotrnāmuttrāsaparivarjanārthaỉ sainvrtyā samāropya tadastīti brūmah.

${ }^{38}$ PP 264, 6-7: anakșarasya dharmasya śrutị kā deśanā ca kā, śrūyate deśyate cārthạ samāropād anakșarah.
} 
gruntu dla świata rzeczy, w którym zakorzeniony jest byt owego świata. Zatem mistyk wie coś istotnego o tym absolucie, wiedzę tę zaś czerpie z poznania natury świata i analizy możliwości istnienia świata obdarzonego taką naturą. Milczenie mistyka jest nie tyle wyrazem słabości poznawczej człowieka, jego poznawczych ograniczeń, co nadzwyczajnego charakteru bytu absolutnego, „nadzwyczajnego”, czyli takiego, który przekracza zdefiniowaną empirycznie zwyczajność. Zatem mistyk wie wiele więcej od sceptyka. Wie, że absolut istnieje, i wie, jaki i czym on nie jest. Milczenie mistyka jest najlepszym znakiem tego, co niewyrażalne. Każde inne słowo bowiem, ze względu na skończoność swojego znaczenia, użyte jako znak doświadczenia mistycznego musi ograniczyć treść tego doświadczenia.

Czwartą formą milczenia, różną od trzech wymienionych, jest milczenie madhjamika. Nim się teraz zajmiemy.

Twierdzę, że cechująca madhjamika rezerwa w stosunku do językowej artykulacji doświadczeń nie wynika z przyrodzonej ułomności języka niezdolnego do ujęcia Tajemnicy absolutnego Bytu, tylko z przeświadczenia, że każda, nawet trafna, tj. prawdziwa artykulacja językowa może stać się przedmiotem egoistycznego lgnięcia. Prawdziwy sąd o rzeczywistości, w przypadku madhjamaki sąd o pustce wszystkich rzeczy, może być tak samo podstawą szkodliwego lgnięcia, jak sąd fałszywy. Nagardżuna wyraził tę myśl, przyrównując sytuację niewłaściwego zrozumienia pustki do złego, niewprawnego uchwycenia żmii (MMK XXIV, 11). Problemem dla madhjamaki jest egotyczna postawa poznającego umysłu, a nie niewystarczalność czy też ułomność języka.

Wypada dodać, iż nie jest to jakaś szczególna cecha teorii madhjamaki. Jest to przekonanie utrwalone w tradycji buddyjskiej na długo przed Nagardżuną. Zgrabną jego ilustrację znajdziemy choćby w Dhammapadzie, gdzie stwierdza się paradoksalnie, iż wiedza rozsadza głowę głupca (DhP V, 72). Paradoks polega na tym, że przecież zgodnie z naturalnym buddyjskim dążeniem do poznania prawdziwego w przekonaniu, iż ono wyzwala, wiedza powinna zmienić głupca w mędrca. Ona jednak działa na jego szkodę, czyniąc z niego idiotę, czyli dostarczając mu pożywki dla trwalszego pogrążenia się w głupocie. Oczywiście nie jest to „wina” wiedzy, tylko samego głupca, jego niezdolności do jej właściwego, zgodnego z jej treścią ujęcia. Przekonanie o posiadaniu prawdy, o byciu jej depozytariuszem, pycha z jej posiadania są najbardziej subtelną formą egotyzmu, na którą wskazuje buddyzm, i sądzę, że jedną z najbardziej szkodliwych, a przynajmniej jedną z najtrudniej usuwalnych ${ }^{39}$.

Wsparcie dla takiej wykładni postawy madhjamaki znajdziemy też w Asztasabasrice. W prowadzonej w pierwszym rozdziale tego tekstu dyskusji między

${ }^{39} \mathrm{Na}$ tle licznych przypowieści i uwag analogicznych do tej z Dhammapady łatwo dostrzec intelektualne impulsy, które popychały buddyjską refleksję z jednej strony w kierunku idei zręcznych środków, z drugiej zaś w kierunku idei bodhisattwy z jego ślubowaniem powstrzymania się od wejścia w ostateczną nirwanę. 
Buddą, Siariputrą i Subhutim pojawia się kwestia określania bodhisattwy mianem „wielkiej istoty”, tj. mahasattwy. Zostaje tam ustalone, że na miano to zasługuje tylko ten, który nie lgnie, nie przywiązuje się ani do myśli o przebudzeniu, ani do myśli o wszechwiedzy, ani do innych doskonałych jakości. Myśl do niczego nielgnąca - stwierdza się tam — jest myślą, która myślą nie jest (cittam acittam). Co niezwykle ważne, w stanie owego braku myśli, owej „bezmyślności", czyli zupełnego nielgnięcia, a więc w stanie doskonałej upekszy nie pojawia się nawet myśl „istnieje” ani „nie istnieje” (AS I, 20) ${ }^{40}$.

Ustalenie to jest ważne dlatego, iż Asztasabasrika nawiązuje tutaj do znacznie wcześniejszego tekstu, mianowicie do Katjajanagotrasutry/Kaczczanagottasutty obecnej w Samjuktagamie/Samjuttanikaji (SN II, 16). Jest to jedyny kanoniczny tekst buddyjski, do którego wprost z tytułu odwołuje się sam Nagardżuna w MMK. Dlatego sądzę, że filozofię madhjamaki nie tylko można, ale wręcz należy odczytywać przez pryzmat przesłania zawartego w tej sutrze.

Nie wdając się w szczegóły, stwierdzimy tylko, że w tekście tym w odpowiedzi na pytanie Katjajany Budda określa parametry właściwego poglądu (s. samyag-driști / p. sammā-dițthi). Właściwy pogląd to taki, w którym unika się orzekania dwóch ekstremów bytu/istnienia i niebytu/nieistnienia. W pułapkę owego przeciwstawienia bytu i niebytu wpada się za sprawą egotycznego lgnięcia do przedmiotów doświadczenia codziennego. Widzący właściwie, jak przebiega łańcuch przyczynowego warunkowania, w którym nie ma miejsca na trwałą jaźń, unikają owej pułapki, kroczą środkową drogą. Istotne w tym tekście jest to, że Budda wiąże żywienie przekonania o bycie/niebycie z postawą lgnięcia i sugeruje, iż widzenie rzeczy, jakimi one są, może się dokonać tylko w stanie całkowitego nielgnięcia, upekszy.

Dopiero w tym kontekście możemy uchwycić sens pozornie prostego przesłania Nagardżuny z MMK XV, 10:

[Stwierdzenie] „istnieje” to pogląd eternalizmu. [Stwierdzenie] „nie istnieje” to pogląd anihilacjonizmu. Dlatego mędrzec nie powinien obstawać przy istnieniu i nieistnieniu ${ }^{41}$.

Nagardżuna nie mówi tu niczego, czego nie bylibyśmy w stanie wyczytać z przywołanych tekstów sutrowych. Obstawanie przy istnieniu bądź nieistnieniu jest wyrazem lgnięcia ugruntowanego w błędnym oglądzie rzeczy.

Jeszcze dobitniej i klarowniej stwierdza to jego uczeń Arjadewa. W Czterystu strofach pisze:

${ }^{40}$ Ratnaguna dodaje $\mathrm{w}$ tym kontekście, że kto nie lgnie, musi porzucić wszystkie nazwy (RGS I, 27). W strofie II, 11 dodaje w podobnym duchu, że „postrzeżenia to tylko słowa” (samiñeti nāma), a ci, którzy się ich wyzbyli, osiągnęli doskonałość (pāramita).

${ }^{41}$ MMK XV, 10: astīti śáśvata-grāho nāstìty uccheda-darśanam, tasmād astitva-nāstitve nāśrīyeta vicakșanạ. 
Niepustego (aśūnya) nie należy uważać za puste (śūnya) [tylko z powodu pragnienia:] „Obym osiągnął nirwanę”. Tathagatowie głoszą, że nirwany nie [osiąga się] dzięki błędnemu poglądowi ${ }^{42}$.

Dlaczego Arjadewa oznajmia, że niepustego nie należy uważać za puste, skoro madhjamaka głosi właśnie, że wszystkie rzeczy są puste? Czym w ogóle miałoby być to niepuste, skoro wszystko jest puste? Dlaczego twierdzenie, że rzeczy są puste, zostaje tutaj uznane za błędny pogląd, który nie zbliża do nirwany? Otóż w strofie tej uczeń Nagardżuny podkreśla, że racją dla takiego orzekania nie może być pragnienie osiągnięcia nirwany, czyli lgnięcie do myśli o nirwanie. Błędność poglądu w tym wypadku nie polega na niewłaściwej treści poglądu, tylko na niewłaściwym stosunku do skądinąd trafnego poglądu. Problemem jest motywacja, nie treść. Nikt nie jest w stanie zmusić się do tego, aby zmienić tezę naturalnego nastawienia, tj. aby uważać za puste rzeczy, które w naturalnym nastawieniu dane nam są jako obdarzone samobytem. Wyzwolenia nie osiąga się wolą, nie osiąga się decyzją, nie osiąga się wreszcie intencją, chociaż ta odgrywa niezwykle ważną rolę w buddyjskiej praktyce duchowej. Wyzwolenie osiąga się dającą się wyrazić w języku wiedzą uzyskaną poprzez bezpośredni ogląd rzeczy, jakimi one są.

Wypowiedź Arjadewy dostarcza doskonałego narzędzia do interpretacji innego słynnego pochodzącego z Odwrócenia krytyki (Vigraba-vyāvartan̄i) stwierdzenia Nagardżuny o nieposiadaniu własnych poglądów. W strofie VV $29 \mathrm{Na-}$ gardżuna oznajmił:

Gdybym głosił jakąś tezę (pratijñā), wtedy popełniałbym błąd. Jednakże nie posiadam żadnej własnej tezy, dlatego nie popełniam błędu ${ }^{43}$.

Nie głosić żadnej tezy, nie mieć poglądu to nie znaczy nie mieć niczego do powiedzenia, nie mieć żadnej propozycjonalnej treści do przekazania. Nie mieć poglądu to znaczy nie mieć egotycznego stosunku do poglądu. Nagardżuna przyznaje, że nie żywi egotycznej postawy względem żadnego poglądu. Żaden

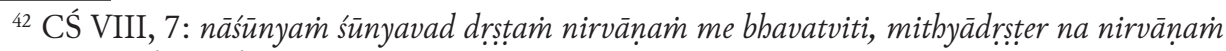
varnayanti tathāgatāh.

${ }^{43} \mathrm{VV}$ 29: yadi kācana pratijūā syān me tata eșa me bhaved doṣah, nāsti ca mama pratijũā tasmān naivāsti me doṣaḥ. Również w tym wypadku Nagardżuna pozostaje wierny wcześniejszej, ogólnobuddyjskiej tradycji. Bez wątpienia bowiem za taką antycypację jego postawy można uznać stwierdzenie z Dhammapady, że przebudzony, czyli arabant (s. arbant), nie ma wierzeń (p. assaddha) (DhP 97). Stwierdzenie to głosi, jak później czyni to Nagardżuna, że przebudzony nie pozostaje z żadnymi przekonaniami, z żadnymi poglądami w relacji egotycznej, o żadnym poglądzie nie może powiedzieć „mój”. Nie oznacza to jednak, że przebudzony nie ma niczego prawdziwego do powiedzenia na temat rzeczywistości. Wszystko jednak, co mówi, mówi w oparciu o widzenie rzeczy, jakimi one są, a nie w oparciu o mniemanie, przeświadczenie czy też zaufanie. 
pogląd nie jest jego, o żadnym nie może powiedzieć „mój”, określając w ten sposób własną emocjonalną więź z jakimś przekonaniem. Nie twierdzi zaś, że żadnej propozycjonalnej treści dającej się dyskursywnie wyrazić w sądzie nie można przypisać wartości prawdy. On sam przecież uznaje za prawdziwy sąd o pustce. Tym samym autor MMK przedstawia siebie jako osobę przebudzoną. Drugorzędną sprawą pozostaje, czy mu w to uwierzymy. Nie ma znaczenia, czy Nagardżuna jest przebudzony, czy tylko kreśli ideał przebudzonego. Istotne jest to, że prezentowana postawa w niczym nie przypomina ani sceptycyzmu, z uporem maniaka od kilkudziesięciu lat wmawianego Nagardżunie oraz czytelnikom jego pism przez wielu współczesnych interpretatorów, ani mistycyzmu.

Zatem powiedzmy to dobitnie. Rezerwy madhjamaki w stosunku do języka nie należy interpretować $\mathrm{w}$ ten sposób, iż bierze się z tego, że doświadczenie rzeczy, jakimi one są, ujawnia ich pustkę (śūnyatā) „będącą podstawą wszelkich form w świecie”, tożsamą z „nicością”, „z której wszystko zostało powołane do bycia - mocą, której można dać imię: Nic jak Bóg” (Bolewski, 2006: 187). Pustki nie można interpretować jako Nicości, jako Tajemnicy Boga, jako nieokreśloności boskiego czy też absolutnego bytu. Interpretacja taka sprowadza naukę madhjamaki do formy negatywnej teologii, z którą nie ma ona nic wspólnego.

Rezerwa madhjamaki wobec języka manifestująca się w preferowaniu negatywnych określeń „takości”, odmowie uznania wykluczających się atrybucji, afirmacji milczenia jako najdoskonalszej postawy względem rzeczywistości jest świadectwem świadomości niebezpieczeństwa egotycznego lgnięcia do przekonań w języku wyrażonych. Rozpoznanie pustki jako negatywnej własności rzeczy, co równoważne jest z widzeniem rzeczy, jakimi one są, stanowi — zdaniem madhjamików - jedyny sposób, aby się przed tym niebezpieczeństwem uchronić.

Musimy zdać sobie sprawę, że milczenie nie zawsze „mówi” to samo. Jego sens ujawnia się tylko w szerszym kontekście afirmowanych i negowanych przekonań. Jeżeli chcemy zatem zrozumieć, co mówi milczenie madhjamików, musimy wsłuchać się w słowa, które je poprzedzają.

Podsumujmy więc. Milczenie madhjamika - owo milczenie szlachetnego (ārjānāìn tūṣnìm-bhāvaḅ) zalecane przez Czandrakirtiego — nie ma nic wspólnego ani z milczeniem sceptyka, ani z milczeniem mistyka, ani tym bardziej z milczeniem (uświadomionej) niewiedzy. Milczenie to wyraża stan doskonałej równowagi umysłu, upekszy, stan doskonałego nielgnięcia, w którym nic nie pozostaje już do powiedzenia. Ale nie pozostaje nie dlatego, że nie ma już co powiedzieć, lecz dlatego, że nie ma już po co mówić. W sytuacji tej jedynym powodem zabierania głosu w jakiejkolwiek sprawie może być wyłącznie potrzeba niesienia pomocy innym utrwalona karmicznie poprzez złożenie ślubów bodhisattwy. 


\section{WIDZENIE PUSTKI A DOŚWIADCZENIE MISTYCZNE}

Buddyjskie doświadczenie nie odsyła do jakiejś tajemniczej Nicości przez odkrycie nicości stworzenia. Buddyjskie doświadczenie jogiczne przynajmniej do czasów madhjamaki jest doświadczeniem tej samej rzeczywistości, o której prawda dostępna jest w racjonalnej analizie filozoficznej. Istotą buddyjskiego medytacyjnego, jogicznego („mistycznego”) doświadczenia nie jest odsyłanie człowieka do Tajemnicy, tylko takie uprzystępnianie dostępnej inną drogą prawdy, które ma moc przemiany istnienia sansarycznego $\mathrm{w}$ istnienie nirwaniczne poprzez wykorzenienie zalążków owego zafałszowanego sposobu istnienia mających charakter szkodliwych nawyków umysłowych.

Trzy rodzaje mądrości (prajña) wyróżniane w buddyzmie nie dotyczą różnych sfer istnienia, nie dotyczą różnych postaw względem istnienia absolutnego/boskiego, lecz różnych form generowania mądrości: poprzez słuchanie (śrutamaȳi), namysł (cintāmaȳi $)$ i medytację (bhāvanāmaȳi $)^{44}$. W swojej treści te trzy rodzaje mądrości nie różnią się od siebie, są jedną mądrością. Buddyjska medytacja zatem nie jest jakimś niezwykłym fundamentem, bez którego filozoficzne rozważania buddyjskie, na przykład na temat braku jaźni, pozostają teorią, która nie tylko szkodzi, ale też nie jest w pełni racjonalna, jak sugerują niektórzy autorzy (Bolewski, 2006: 149). Buddyjska medytacja nie ujawnia jakiegoś ukrytego ontycznego dna niedostępnego buddyjskiej racjonalnej analizie, jakiegoś obszaru, „do którego rozum ze swoim świattem sięga tylko częściowo” (Bolewski, 2006: 149). Filozoficzna teoria, nawet będąc prawdziwą, może być szkodliwa o tyle, o ile może stać się w swoim werbalnym wyartykułowaniu przedmiotem lgnięcia, które wzmacnia poczucie ego. Poznanie medytacyjne przekształca medytującego w ten sposób, iż owa szkodliwa postawa lgnięcia nie może się pojawić. Dzięki temu takie poznanie wyzwala.

Wartość wglądu poznawczego uzyskanego na drodze medytacji nie wyraża się w tym, iż udostępnia on nową, doskonałą, ostateczną, w inny sposób niedostępną prawdę o rzeczywistości, tym bardziej nie wyraża się w tym, iż uchwytuje on inną, ukrytą pod mnogością zjawisk doskonalszą rzeczywistość, tylko w tym, iż trwale usuwa te czynniki umysłowe o charakterze nawyków, które konstytuują naszą sansaryczną postawę wyrażającą się w egoistycznym lgnięciu wyrastającym z przedświadomego przeświadczenia o ostatecznej, w nich samych ufundowanej realności przedmiotów doświadczenia. To przeświadczenie nazwałem za Edmundem Husserlem „generalną tezą naturalnego nastawienia”. Pod tym względem postawa madhjamaki jest zgodna z postawą całej tradycji abhidharmicznej. Novum polega wyłącznie na tym, iż kładzie ona skrajnie

${ }^{44}$ Podział ten jest powszechnie znany w tradycji buddyjskiej i przywoływany przez przedstawicieli różnych szkół, na przykład zarówno przez Wasubandhu (Abbidbarma-kośa), jak i Kamalasilę (Bhāvanākrama). 
intensywny nacisk na de-substancjalizację rzeczywistości przedmiotowej. Madhjamaka zdaje się twierdzić, iż dla uzyskania doskonałej równowagi umysłu (upekszy) wstępna de-substancjalizacja podmiotu poprzez rozłożenie go na skandhy (i dharmy) nie wystarcza.

Buddyjskie doświadczenie medytacyjne jest zatem inną formą poznania tej samej prawdy, która dostępna jest na drodze racjonalnej analizy. W przypadku madhjamaki można powiedzieć, że praktyka medytacyjna służy doskonaleniu owej analizy czy też że wręcz ją stanowi.

Porównanie do fenomenologii Husserla uważam za wartościowe i nośne. Sytuacja, jaką opisuje madhjamaka, zdaje się być tą samą, która stanowi punkt wyjścia refleksji niemieckiego filozofa. Podkreślić jednak należy, że tam, gdzie Husserl zaczyna, tam madhjamaka kończy. Husserl sądzi, że aby zbudować obiektywną wiedzę, należy dotrzeć do tego dotychczas nieodkrytego miejsca, w którym dokonuje się sama konstytucja przedmiotu poznania. Temu ma służyć redukcja fenomenologiczna, która w postaci epoche jest zawieszeniem obowiązywania tezy naturalnego nastawienia, czyli przeświadczenia o realności doświadczanych przedmiotów. Gdy ją przeprowadzimy, otworzy się nowy, dotychczas niezbadany obszar poznawczy.

Z perspektywy madhjamaki projekt Husserla jawi się jako skrajnie naiwny. Niemiecki filozof traktuje błąd poznawczy jako coś, co nam się przytrafia. Co prawda do czasów Husserla przytrafiało się zawsze, ale dalej tylko przytrafiało. Madhjamaka zaś w zgodzie z całą poprzedzającą ją tradycją buddyjską uznaje, że błąd poznawczy jest tym, co nas konstytuuje jako poznające błędnie podmioty, jest tym, co funduje naszą sansaryczną empiryczną egzystencję. Zawiesić generalną tezę naturalnego nastawienia to z perspektywy madhjamaki zmienić naszą kondycję z sansarycznej na nirwaniczną. Husserl postuluje, aby zrobić to aktem teoretycznej decyzji (Husserl, 1975: 88-92). Mówiąc językiem buddyjskiej teorii medytacji, Husserl wierzy, że do osiągnięcia upekszy wystarcza czysta intelektualna operacja.

Husserl jest jednym z wielu europejskich myślicieli mających swojego patrona w Kartezjuszu, którzy poznawczą praktykę wyrywali z praktyki życiowej. Wierzyli, iż proces poznawczy można skutecznie odizolować od umysłowych sił wpływających na charakter i jakość naszej życiowej praktyki, czyli na nasze zachowania, wybory, reakcje emocjonalne, skłonności itd., gdyż proces ten jest domeną odmiennej umysłowej/psychicznej władzy. Wyrwanie praktyki poznawczej z praktyki życiowej wiąże się z nadaniem temu obszarowi naszej osoby, który ową praktykę poznawczą funduje, czyli świadomości, szczególnego, wyróżnionego ontycznego statusu.

Rację mieli wszyscy ci krytycy koncepcji epoche, którzy dowodzili, iż spycha ona Husserla na stanowisko idealizmu, przesądzając na wstępie o nadzwyczajnym i nadrzędnym sposobie istnienia świadomości, o jej absolutności (Ingarden, 1974: 221-224). 
Warto zwrócić na ten fakt uwagę, gdyż analogiczny proces zaobserwować można $\mathrm{w}$ późnym indyjskim buddyzmie. To samo zdają się robić zwolennicy literalnie pojmowanej idei tathagatagarbhy, którzy utożsamiają dobrze ugruntowaną w abhidharmicznej teorii dharm, wręcz naturalną dla tej teorii i niebudzącą wielkich kontrowersji ideę czystości świadomości z przekonaniem o jej absolutnym statusie ontycznym.

Te ogólne rozważania chciałbym zakończyć odniesieniem do współczesnego japońskiego autora buddyjskiego, który uzyskał popularność nie jako filozof, lecz jako mistrz duchowy tradycji soto zen, Shunryu Suzukiego. Mimo deklarowanej rezerwy w stosunku do wszelkiej filozofii, w tym także filozofii buddyjskiej, co pozostaje w zgodzie z potocznymi wyobrażeniami na temat postawy zen, stwierdza on z jednej strony, iż: „Filozofia buddyjska jest tak uniwersalna i logiczna, że nie jest to filozofia buddyzmu, ale samego życia”, z drugiej zaś zauważa, że: „W niektórych wypadkach buddyzm skłania się do polemiki [...], bowiem buddyści muszą zabezpieczyć swoją drogę przed mistycznymi czy magicznymi interpretacjami religii" (Sh. Suzuki, b.r.w.: 121).

Filozoficzna wykładnia nie jest kwestią wtórną, co sugeruje wielu badaczy doświadczenia mistycznego. Zabezpieczając drogę każdej praktyki duchowej (religii), jest ona znakiem różnicy nie tylko filozoficzno-teologicznych interpretacji, ale także, a może przede wszystkim, różnicy samych doświadczeń leżących u podstaw owych wykładni. Dla osiągnięcia przebudzenia istotne jest bowiem nie tylko, jak się doświadcza/wierzy, ale także czego się doświadcza / w co się wierzy.

\section{BIBLIOGRAFIA}

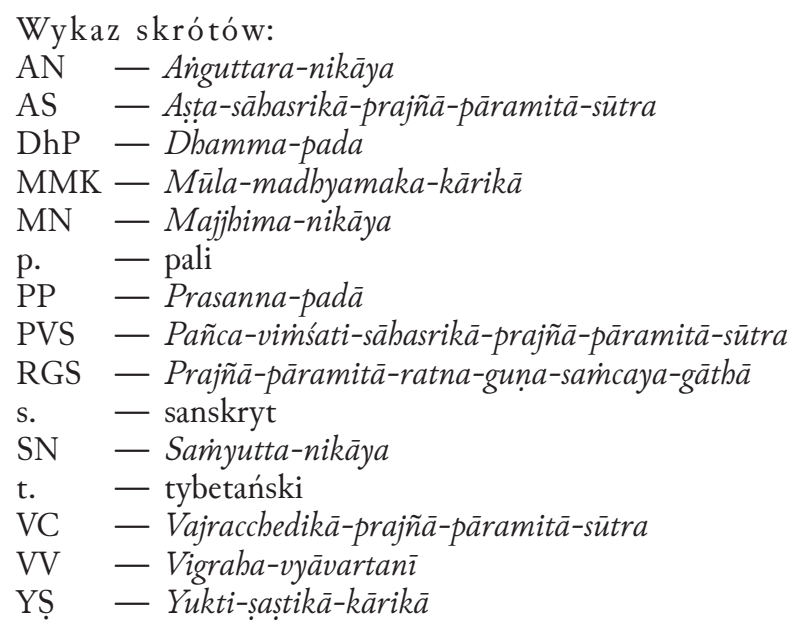


Teksty źródłowe:

Añguttara-nikāya

Añguttara-nikāya (1885-1900). (Red. R. Morris \& E. Hardy). T. 1-5. London: Pali Text Society.

Āryadeva, Catub-śataka

Lang, K. (1986). Arryadeva's Catubśataka: On the Bodbisattva's cultivation of merit and knowledge. Delhi: Motilal Banarsidass Publishers.

Asța-sābasrikā-prajñā-pāramitā-sūtra

Mitra, R. (Red.). (1888). Ashtasāhasrikā. Calcutta: The Asiatic Society of Bengal.

Conze, E. (Przet.). (1975). The perfection of wisdom in eight thousand lines and its verse summary (wyd. 2). Bolinas: Four Seasons Foundation.

Vaidya, P. L. (Red.). (1960). Aștasāhasrikā Prajñāpāramitā. Darbhanga: The Mithila Institute. [Reprint: University of Oslo, Bibliotheca Poliglota: Thesaurus Literaturae Buddhicae: Astasāăhasrikā Prajñāpāramitā. On-line: http://www2.hf.uio.no/common/apps/ permlink/permlink.php?app=polyglotta\&context $=$ volume\&uid=71f3de9e-5528-11e4856a-001cc4ddf0f4 (dostęp: 11.07.2017)].

Candrakīrti, Prasanna-pad̄̄

La Vallée Poussin, L. de (Red.). (1903). Mūlamadhyamakakārikās (Mādhyamikasūtras) de Nāgārjuna avec la Prasannapadā commentaire de Candrakìrti. St. Petersbourg: L’Académie Impériale des Sciences.

Vaidya, P. L. (Red.). (1960). Madhyamakaśāstra of Nāgārjuna with the commentary: Prasannapadā by Candrakirti. Darbhanga: The Mithila Institute.

Dhamma-pada

Radhakrishnan, S. (Wyd. i tłum.). (1950). The Dhammapada with introductory essays, Pāli text, English translation and notes, London-New York-Toronto: Oxford University Press.

Majjbima-nikāya

Majjhima-nikāya (1888-1902). (Red. V. Trenckner \& R. Chalmers). T. 1-3. London: Pali Text Society.

Nāgārjuna, Mūla-madhyamaka-kārikā

Jong, J. W. de (Red.). (1977). Mülamadhyamakakārikāḥ. Madras: The Adyar Library and Research Centre.

La Vallée Poussin, L. de (Red.). (1903). Mūlamadhyamakakārikās (Mādhyamikasūtras) de Nāgārjuna avec la Prasannapadā commentaire de Candrakìrti. St. Petersbourg: L’Académie Impériale des Sciences.

Vaidya, P. L. (Red.). (1960). Madhyamakaśästra of Nāgärjuna with the commentary: Prasannapadā by Candrakirti. Darbhanga: Mithila Institute.

Nāgārjuna, Vigraba-vyāvartan̄

Johnston, E. H. \& Kunst, A. (Red.). (1948-1951). Vigrahavyāvartañ̄ of Nāgārjuna. Mélanges chinois et bouddhiques, 9, 99-152. [Przedruk w: Bhattacharya, K. (1990). The dialectical method of Nāgārjuna. Vigrahavyāvartanī. Delhi: Motilal Banarsidass Publishers]. 
Nāgārjuna, Yukti-șaștikāākārikā

Lindtner, Ch. (1990). Nagarjuniana: Studies in the writings and philosophy of Nāgārjuna. Delhi: Motilal Banarsidass Publishers.

Pañca-vimíati-sāhasrikā-prajūā-pāramitā-sūtra

Dutt, N. (Red.). (1934). Pañcavimiśatisābasrikā Prajñāpāramitā. London: Luzac and Co. [Reprint: GRETIL - Göttingen Register of Electronic Texts in Indian Languages. On-line: http:/gre til.sub.uni-goettingen.de/gretil/1_sanskr/4_rellit/buddh/pspduttu.htm (dostęp: 11.07.2017)].

Prajñā-pāramitā-ratna-guna-saincaya-gāthā

Vaidya, P. L. (Red.). (1961). Mabāyāna-sūtra-saíngrabạ̣ (cz. 1). Darbhanga: The Mithila Institute. [Reprint: Digital Sanskrit Buddhist Canon. On-line: http://www.dsbcproject.org/ canon-text/book/72 (dostęp: 11.07.2017)].

Saimyutta-nikāya

Samyutta-nikāya (1884-1898). (Red. L. Feer). T. 1-5. London: Pali Text Society.

\section{Vajracchedikā-prajī̄a-pāramitā-sūtra}

Harrison, P. \& Watanabe, Sh. (Red.). (2006). Vajracchedikā Prajñāpāramitāa (=Buddhist Manuscripts in the Schøyen Collection, 3). Oslo: Hermes Academic Publishing. [Reprint: University of Oslo. Bibliotheca Poliglota: Thesaurus Literaturae Buddhicae: Vajracchedikā Prajñāpāramitā. On-line: http://www2.hf.uio.no/common/apps/permlink/permlink.php?app=polyglotta\&co ntext=volume\&uid=21af821c-0cb2-11df-9e60-00215aecadea (dostęp: 11.07.2017)].

Opracowania:

Ames, W. L. (1982). The notion of svabbāva in the thought of Candrakīrti. Journal of Indian Philosophy, 10/2, 161-177.

Bareau, A. (1951). L'absolu en philosopbie boudhique. Paris: Centre de Documentation Universitaire.

Bolewski, J. (2006). Daleki Wschód na Zachodzie. Od reinkarnacji do regeneracji. Kraków: WAM.

Burton, D. (2000). Wisdom beyond words? Ineffability in Yogācāra and Madhyamaka Buddhism. Contemporary Buddhism, 1/1, 53-76.

Byrski, M. K. (2008). Przekaz tekstów objawionych i normatywnych w tłumaczeniach, czyli praktyka zależnego powstawania. Przegląd Orientalistyczny, 226-227, 153-172.

Collinson, D., Plant, K., \& Wilkinson, R. (2002). Fifty eastern thinkers. London-New York: Routledge.

Conze, E. (1952). The composition of the Astasābasrikā Prajñāpāramitā. Bulletin of the School of Oriental and African Studies, 14/2, 251-262.

Heisig, J. W. (2001). Philosophers of nothingness: An essay on the Kyoto school. Honolulu: University of Hawai'i Press.

Husserl, E. (1975). Idee czystej fenomenologii i fenomenologicznej filozofii. Ksiega pierwsza. (Przeł. D. Gierulanka). Warszawa: Państwowe Wydawnictwo Naukowe.

Huxley, A. (1991). Drzwi percepcji. (Przeł. P. Kołyszko). Warszawa: Wydawnictwo Przedświt.

Ingarden, R. (1974). Wstęp do fenomenologii Husserla. (Przeł. A. Półtawski). Warszawa: Państwowe Wydawnictwo Naukowe.

Jakubczak, K. (2010). Madbjamaka Nagardżuny. Filozofia czy terapia?. Kraków: Księgarnia Akademicka.

James, W. (2001). Doświadczenia religijne. (Przeł. J. Hempel). Kraków: Zakład Wydawniczy NOMOS. 
Jones, R. H. (1993). Mysticism examined: Philosophical inquiries into mysticism. Albany: SUNY Press.

Jones, R. H. (2016). Philosophy of mysticism: Raids on the ineffable. Albany: SUNY Press.

Kozyra, A. (2007). Filozofia nicości Nishidy Kitarō. Warszawa: Nozomi.

La Vallée Poussin, L. de (1936-1937). Musīla et Nārada. Le chemin du nirvāṇa. Mélanges chinois et bouddhiques, 5, 189-222. [Musīla and Nārada. The Path of Nirvāna, (Przet. na j. angielski G. M. Chödrön \& G. L. Sangpo). On-line: http://www.gampoabbey.org/ kosha-resources.php (dostęp: 10.03.2015)].

Matial, B. K. (1975). Mysticism and reality: Ineffability. Journal of Indian Philosophy, 3, 217-252.

Matial, B. K. (2005). Epistemology, logic, and grammar in Indian philosophical analysis. New Edition. (Red. J. Ganeri). Oxford: Oxford University Press.

Murti, T. R. V. (1960). The central philosophy of Buddbism. London: George Allen and Unwin.

Norman, K. R. (1989). On translating the Dhammapada. Buddhist Studies Review, 6/2, 153-165.

Otto, R. (2000). Mistyka Wschodu i Zachodu. Analogie i różnice wyjaśniajace jej istotę. (Przeł. T. Duliński). Warszawa: Wydawnictwo KR.

Pyysiäinen, I. (1993). Beyond language and reason: Mysticism in Indian Buddhism. Helsinki: Suomalainen Tiedeakatemia.

Schayer, S. (1931). Ausgewählte Kapitel aus der Prasannapadā. Kraków: Polska Akademia Umiejętności.

Scholem, G. (2007). Mistycyzm żydowski i jego główne kierunki. (Przeł. I. Kania). Warszawa: Wydawnictwo Aletheia.

Schopen, G. (1975). The phrase 'sa prtbivīpradeśaś caityabbūto bhavet' in the Vajracchedikā: Notes on the cult of the book in Mahāyāna. Indo-Iranian Journal, 17, 147-181.

Smart, N. (2000). Mysticism and scripture in Theravāda Buddhism (s. 232-241). W: S. T. Katz (Red.). Mysticism and sacred scripture. Oxford: Oxford University Press.

Stace, W. T. (1961). Mysticism and philosophy. London: Macmillan and Co.

Stcherbatsky, T. (1927). The conception of Buddhist nirvanna. Leningrad: The Academy of Sciences of the USSR.

Suzuki, D. T. (1955). An interpretation of Zen-experience (1939) (s. 61-84). W: D. T. Suzuki. Studies in Zen. New York: A Delta Book.

Suzuki, D. T. (1992). Wprowadzenie do buddyzmu zen. (Przeł. M. \& A. Grabowscy). Warszawa: Wydawnictwo Przedświt.

Suzuki, D. T. (2002). Mysticism: Christian and Buddhist. London-New York: Routledge. [Wyd. 1: 1957].

Suzuki, D. T. (2009). Zen i kultura japońska. (Przeł. B. Szymańska et al.). Kraków: Wydawnictwo Uniwersytetu Jagiellońskiego.

Suzuki, Sh. (B.r.w.). Umyst zen, umyst poczatkujacego. (Przeł. J. Dobrowolski \& A. Sobota). B.m.w.

Szahaj, A. (1993). Teksty na wolności. Kultura Wspótczesna, 2, 5-13.

Tanji, T. (2000). On samāropa. Probing the relationship of the Buddha's silence and his teaching (s. 347-368). W: J. Silk (Red.). Wisdom, compassion, and the search for understanding: The Buddhist studies legacy of Gadjin M. Nagao. Honolulu: University of Hawai'i Press.

Tillemans, T. J. F. (2001). Trying to be fair to Mädhyamika Buddhism. Calgary: The University of Calgary.

Williams, P. (1989). Mabāyāna Buddhism: The doctrinal foundations. New York: Routledge.

Yao-ming, Tsai (2014). Language as an instrument of soteriological transformation from the Madhyamaka perspective. Asian Philosopby, 24/4, 330-345.

Zaehner, R. Ch. (1971). Mysticism, sacred and profane. Oxford: Oxford University Press. 